\title{
A profile of tourists visiting the Kruger National Park
}

\author{
M. SaAyman and E. SlabberT
}

Saayman, M. and E. Slabbert. 2004. A profile of tourists visiting the Kruger National Park. Koedoe 47(1): 1-8. Pretoria. ISSN 0075-6458

Due to shrinking budgets for conservation and an increase in the number of government and privately owned parks, it has become very important for parks to determine who the tourists are who visit one of South Africa's top tourist attractions. The reason for this is that park management and marketers need to focus their efforts to optimise their limited resources. This can only be done once there is a clear understanding of who the market is, where they come from and what they expect. The literature study clearly showed that market segmentation is essential for the effective marketing of a tourism product or destination. Two surveys were conducted, one in 2001 and a follow-up study in 2002, profiling tourists to the Kruger National Park. Different months were chosen to conduct the two surveys in order to get a more comprehensive profile of tourists visiting the park in different seasons.

Key words: market segmentation, profile, market, tourism, tourist/s, tourism industry, Kruger National Park.

M. Saayman and E. Slabbert, Institute for Tourism and Leisure Studies, Potchefstroom University for CHE, Private Bag X6001, Potchefstroom, 2520 Republic of South Africa (ontms@puknet.puk.ac.za).

\section{Introduction}

One of the world's best-known and most profitable national parks, the Kruger National Park (KNP) in the Republic of South Africa, was established in 1898 as the Sabie Game Reserve. The park is one of the largest parks in the world, with the main aim to protect the biodiversity of the region. The latter includes 147 mammal species, 500 species of birds, 116 species of reptiles, 34 species of amphibians, 49 species of fish, 457 species of trees and shrubs, 1500 species of smaller plants and countless species of insects (Dennis 2000). The KNP covers a total surface area of $19624 \mathrm{~km}^{2}$, with a total length of $350 \mathrm{~km}$ and an average width of $60 \mathrm{~km}$. Most of the park consists of flat grass and bushcovered plains, interrupted by the low Lebombo Mountains situated along the border of Mozambique. Negotiations are under way with neighbouring countries which will significantly enlarge the park to form the Limpopo Transfrontier Conservation Area. This will be the largest national park in the world. Approximately 950000 people visit this park each year, of which $80 \%$ are South Africans.

To ensure continuity and growth, a destination (attraction) is dependent on, inter alia, tourists and the satisfaction of their needs. Although total satisfaction of tourists' needs are not the goal in itself, striving to achieve this enables the attraction to attain its own goals (Strydom et al. 2000). To achieve maximum tourist satisfaction, marketing strategists divide the heterogeneous market into fairly homogeneous groups of tourists, a process that is referred to as market segmentation. Through market segmentation one can develop a tourist profile that will enable KNP to concentrate its resources and efforts so that maximum penetration of that market can be achieved (Doole \& Lowe 2001).

However, little is known about tourists who visit the park. The problem that KNP must deal with is that the 'product' sought by tourists can be satisfied by a number of attractions/destinations. This creates the need to develop an overall competitive advantage for KNP (Hassan 2000) and makes the pro- 
filing of tourists crucial (Nickels \& Wood 1997). The number of parks and game reserves in South Africa are on the increase, which leads to stiff competition. Except for national parks, there are also parks at local, provincial and government levels, as well as more than 8000 privately owned game reserves. All these parks and game reserves are offering an ecotourism experience. Other destinations/attractions are winning competitive battles through careful analysis and response to the core values and needs of the segmented travel market place (Hassan 2000). KNP needs to do the same. With regard to the international travel to South Africa, research by South African Tourism indicated that more than $80 \%$ of these tourists travel to South Africa for game and nature experiences (SAT 2002). This creates yet another opportunity for marketers to profile tourists travelling to the KNP (SAT 2002).

It is no longer possible to serve a total market and it is therefore necessary to segment markets and concentrate on a single segment or a number of segments (Saayman 2001; Kinnear et al. 1995). Segments are evaluated according to a number of criteria, but the essence of the approach is to identify the most relevant characteristics of tourists seeking particular sets of benefits from their tourism and leisure purchases (Laws 1997; Pride \& Ferrell 1987). In this process, consumer behaviour plays an important role. The tourist does not make purchase decisions in isolation. The mix of cultural, social, personal, psychological factors and previous experiences, all which influence behaviour, is largely uncontrollable. Because of the influence exerted upon patterns of buying, it is essential that as much effort as possible is put into understanding how these factors interact and ultimately how they influence decisions (Lamb et al. 2002). The attractiveness of KNP reflects the feelings, beliefs and opinions that an individual has about the park's ability to provide satisfaction in relation to his or her special vacation needs (Slabbert 2002).
Successful segmentation is the product of a detailed understanding of the market and will therefore take time (Saayman 2001; McDonald \& Dunbar 1995). Market segmentation is also one of the keys to developing a sustainable competitive advantage based on differentiation, low cost, or a focused strategy (Aaker 1998). Knowing the profile characteristics of target groups can help marketing strategists to tailor the product or service and promote the product or service more effectively. Each group can be targeted and reached with a distinct marketing mix (McDonald \& Dunbar 1995). Communication effects have a direct bearing on the prospective tourist's decision to act. The prospective tourist decides whether or not to respond to the advertising by taking action (Pritchard 1998). To be of use, markets need to be segmented according to attributes that can relate to the product or service, distribution, price and media (Andereck \& Caldwell 1994).

Benefits of market segmentation include:

- long-term relationships can be formed with tourists who are brand loyal (Nickels \& Wood 1997);

- gauging the park's current position, as it is perceived by the tourists, relative to the competition;

- segmentation can help guide the proper allocation and use of marketing resources (Strydom et al. 2000; Semenik 2002);

- new markets can be detected and the success of marketing campaigns can be measured;

- scarce resources are not wasted and the marketing message/communication can be very specific;

- skills and insights used in segmenting the product market give the KNP an important competitive advantage by identifying buyer groups that will respond favourably to the park's marketing efforts (Slabbert 2002);

- long-term growth can be secured by understanding each tourist market as an individual group of tourists with their distinct cultural make-up (Reisinger \& Turner 1998); 
- better service and facilities can be delivered (Saayman 2001).

It is therefore important for the KNP to profile the target market accurately and to understand its diversity. The profiling of a tourist typically involves four components, namely demographic, geographic, psychographic and socio-economic characteristics (Saayman 2001 \& Kotler et al. 1999).

Based on the above, the purpose of this paper is to determine the profile of the typical tourist visiting The Kruger National Park. This information will help park management and marketers in the formulation of marketing policies and development strategies in order to maintain a competitive advantage.

\section{Methods}

The methodology used in this research was twofold, namely a literature study and two surveys. The literature study focused on similar research as well as marketing literature in order to compile a questionnaire. Research by Kotler et al. (1999) and Saayman (2001) gave insight into what aspects are relevant for the development of a profile of tourists to the park.

The surveys were conducted in the KNP by means of questionnaires completed by field-workers whilst interviewing tourists. The 2001 survey was completed during the first two weeks of May and the 2002 survey was completed during the first two weeks of July. The reason for this was because the months of May to July are rated as shoulder to high season and it is also the best time of the year to view game in this park. A random sampling method was used to determine the number of tourists who should form part of the survey. Interviews with 220 people were conducted in 2001. Camps included in the study were: Berg en Dal (75), Satara (68), Shingwedzi (34) and Olifants (40). A total of 323 questionnaires were completed in 2002, viz., in Berg en Dal (62), Olifants (93), Shingwedzi (81) and Satara (87) (Fig. 1). The number of participants was determined by the availability of tourists and bed capacity. A structured questionnaire was used. The questionnaire dealt with demographic, socio-economic, geographic and psychographic information. Respondents had to rate aspects on a five-point Likert scale, where:

$1=$ less important, $5=$ very important.

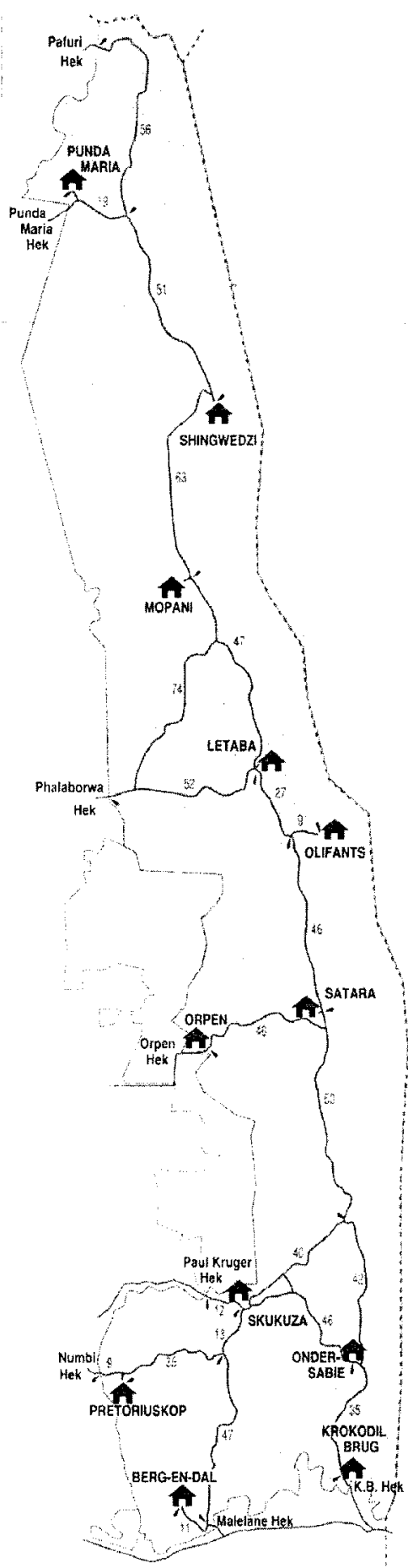

Fig. 1. Map of the Kruger National Park. 
Table 1

Demographic profile

\begin{tabular}{lrlrl}
\hline & 2001 & & 2002 & \\
\hline Gender & $64 \%$ & Male & $66 \%$ & Male \\
& $36 \%$ & Female & $34 \%$ & Female \\
Language & $54 \%$ & Afrikaans & $68 \%$ & Afrikaans \\
& $40 \%$ & English & $26 \%$ & English \\
Marital status & $5 \%$ & Xhosa & $4.7 \%$ & Other languages \\
& $78 \%$ & Married & $85 \%$ & Married \\
& $11 \%$ & Unmarried & $9 \%$ & Not married \\
Size of travelling group & $6 \%$ & Living together & $3 \%$ & Living together \\
& $68 \%$ & 1 to 2 & $47 \%$ & 3 to 4 people \\
& $24 \%$ & 3 to 4 & $30 \%$ & 5 to 10 people \\
Occupation & $8 \%$ & 5 or more & $18 \%$ & 1 to 2 people \\
& $27 \%$ & Professional & $43 \%$ & Professional \\
& $22 \%$ & Other & $14 \%$ & Managerial \\
& $17 \%$ & Managerial & $10 \%$ & Other \\
\hline
\end{tabular}

Table 2

Socio-economic profile

\begin{tabular}{lllll}
\hline & 2001 & & 2002 & \\
\hline Annual income & $24 \%$ & R 50 001 - R 100 000 & $16 \%$ & R100 001 - R150 000 \\
& $13 \%$ & R100 001 - R 150000 & $15 \%$ & R50 001 - R 100 000 \\
& $12 \%$ & R150 001 - R 200 000 & & \\
Education & $35 \%$ & Diploma/degree & $45 \%$ & Diploma/degree \\
& $31 \%$ & Matric/Equivalent & $18 \%$ & Post graduate \\
& $18 \%$ & Professional & $20 \%$ & Matric \\
Mode of transport & $36 \%$ & Sedan & $30 \%$ & Sedan \\
& $18 \%$ & 4 x 4 & $20 \%$ & 4 x 4 \\
& $15 \%$ & Leisure vehicle & $18 \%$ & Kombi \\
Expenditure & & R 3500 per travelling & & R 4440 per travelling \\
& & group per trip & & group per trip \\
\hline
\end{tabular}

Table 3

Geographic profile

\begin{tabular}{lllll}
\hline & 2001 & & 2002 & \\
\hline Province & $39 \%$ & Gauteng & $42 \%$ & Gauteng \\
& $11 \%$ & Northern Province & $20 \%$ & Western Cape \\
& & & $8 \%$ & Free state \\
Country of residence & $11 \%$ & Other countries & $22 \%$ & USA \\
& & & $22 \%$ & Australia \\
& & & $19 \%$ & UK \\
\hline
\end{tabular}


For the purpose of this article, certain aspects of the market segmentation model most frequently used in tourism research was applied (Saayman 2001; Kotler et al. 1999; Proctor 1996; Pender 1999; Nickels \& Wood 1997). This segmentation model is used in profiling a specific market according to:

- demographic information, e.g., age, gender, income, marital status, education and nationality;

- socio-economic information, for example spending patterns;

- $\quad$ psychographic information, for example reasons for attending and most effective marketing tools; geographic information, e.g., where tourists come from.

\section{Results}

From the surveys the following results were obtained. Only the three highest percentages in each category are indicated in the results, therefore the total of some of the percentages will not equal $100 \%$.

\section{Demographic profile}

From Table 1 it is clear that in both years the respondents are mostly married, Afrikaansspeaking tourists who travel in groups of approximately three people and practise a professional occupation.

\section{Socio-economic profile}

Table 2 shows that the respondents' annual income varies between R 50001 and R 150 000. Most of the tourists are well-educated and this supports the notion that they are in professional occupations. Their most common mode of transport is sedan vehicles, and the second-most common mode of transport is $4 \times 4$ vehicles. The average expenditure per travelling group in 2002 has increased by $26.8 \%$ compared to 2001 .

\section{Geographic profile}

Tourists to this park are mainly South Africans who reside in the Gauteng province. However, the 2002 survey indicated an increase in tourists from the Limpopo and Western Cape provinces. This could be due to the school holidays in July, compared to May which is not a school holiday month. In July, international tourists were mostly from the USA (22\%), Australia (22\%) and the UK $(19 \%)$.

\section{Psychographic profile}

More than $50 \%$ of the tourists in both surveys (Table 4) indicated that they had visited one of the national parks on average three times per year. This is an indication that most of the respondents are loyal. From a parks management perspective, it is necessary to maintain a high quality of service to persuade these tourists to return annually. The reasons for visiting this park are: to view the variety of animal life; to relax; and to break away from their normal routine. The decision to travel to KNP was made at least three weeks in advance and the respondents stayed between four and seven days.

From Table 5 it may be concluded that family and friends are an important source of information for tourists. Word of mouth was followed by magazines, specifically the Getaway, Caravan and Outdoor Life, as well as OutThere. The newspapers that are read most by respondents are the Rapport and Beeld. This correlates with the fact that these tourists are mainly Afrikaans-speaking. Television programmes most enjoyed by respondents are news and current affairs, as well as documentaries.

\section{Profile of the tourist}

In order to make sense of the information obtained above, Plog (1976) recommended the personification of target groups, so that dull statistics are transposed into a 'living' profile to which economists and marketers can respond more easily. Using this approach introduced by the Plog research group, the typical tourist to the Kruger National Park is personified as Chris and Penny Steyn.

Chris and Penny Steyn are living in Pretoria, in Gauteng province in the Republic of South Africa. They are Afrikaans-speaking and have a son, Chris junior. Chris (senior) is 
Table 4

Personality type

\begin{tabular}{|c|c|c|c|c|}
\hline & 2001 & & 2002 & \\
\hline \multicolumn{5}{|l|}{ Personality type } \\
\hline Preferred leisure activities & $\begin{array}{l}88 \% \\
78 \% \\
72 \%\end{array}$ & $\begin{array}{l}\text { Game viewing } \\
\text { Travel } \\
\text { Reading }\end{array}$ & $\begin{array}{l}90 \% \\
67 \% \\
20 \%\end{array}$ & $\begin{array}{l}\text { Game viewing } \\
\text { Travel } \\
\text { Movies }\end{array}$ \\
\hline \multicolumn{5}{|l|}{ Buying behaviour } \\
\hline $\begin{array}{l}\text { Frequency of visits to } \\
\text { national parks (per year) }\end{array}$ & $\begin{array}{l}51 \% \\
20 \% \\
14 \%\end{array}$ & $\begin{array}{l}2-5 \text { Times } \\
\text { Once } \\
5-10 \text { Times }\end{array}$ & $\begin{array}{l}58 \% \\
27 \% \\
11 \%\end{array}$ & $\begin{array}{l}2-5 \text { Times } \\
\text { Once } \\
5-10 \text { Times }\end{array}$ \\
\hline Preference of the park & $\begin{array}{l}42 \% \\
22 \% \\
18 \%\end{array}$ & $\begin{array}{l}\text { Variety of wildlife } \\
\text { Beautiful nature } \\
\text { Wilderness experience }\end{array}$ & $\begin{array}{r}59 \% \\
15 \% \\
9 \%\end{array}$ & $\begin{array}{l}\text { Variety of wildlife } \\
\text { Wilderness experience } \\
\text { Other }\end{array}$ \\
\hline Reason for visiting & $\begin{array}{l}82 \% \\
78 \% \\
66 \%\end{array}$ & $\begin{array}{l}\text { To relax } \\
\text { To get away from my } \\
\text { regular routine } \\
\text { To learn about animals } \\
\text { in general }\end{array}$ & $\begin{array}{l}61 \% \\
49 \% \\
35 \%\end{array}$ & $\begin{array}{l}\text { To relax } \\
\text { To get away from my } \\
\text { regular routine } \\
\text { For the benefit of my children }\end{array}$ \\
\hline Length of stay & $\begin{array}{l}35 \% \\
26 \% \\
16 \%\end{array}$ & $\begin{array}{l}4 \text { - } 7 \text { Days } \\
7 \text { - 14 Days } \\
2 \text { - } 4 \text { Days }\end{array}$ & $\begin{array}{l}34 \% \\
33 \% \\
24 \%\end{array}$ & $\begin{array}{l}7 \text { - } 14 \text { Days } \\
4 \text { - } 7 \text { Days } \\
2 \text { - } 4 \text { Days }\end{array}$ \\
\hline Private game reserves & $\begin{array}{l}64 \% \\
36 \%\end{array}$ & $\begin{array}{l}\text { No } \\
\text { Yes }\end{array}$ & $\begin{array}{l}63 \% \\
37 \%\end{array}$ & $\begin{array}{l}\text { No } \\
\text { Yes }\end{array}$ \\
\hline Booking arrangements & $\begin{array}{r}66 \% \\
19 \% \\
8 \% \\
\end{array}$ & $\begin{array}{l}21+\text { Days } \\
1-7 \text { Days } \\
15-21 \text { Days }\end{array}$ & $\begin{array}{r}84 \% \\
8 \% \\
4 \%\end{array}$ & $\begin{array}{l}21+\text { Days } \\
1-7 \text { Days } \\
15-21 \text { Days }\end{array}$ \\
\hline
\end{tabular}

Table 5

Media usage

\begin{tabular}{lllll}
\hline & 2001 & & 2002 & \\
\hline Came to hear of the park & $51 \%$ & Family and friends & $64 \%$ & Family and friends \\
& $24 \%$ & Magazines & $27 \%$ & Other \\
& $12 \%$ & SANPARKS & $5 \%$ & SA Tourism \\
Magazines & $54 \%$ & Getaway & $66 \%$ & Getaway \\
& $44 \%$ & Caravan and outdoor life & $68 \%$ & OutThere \\
& $36 \%$ & Timbila & $60 \%$ & Caravan and outdoor life \\
Newspapers & $40 \%$ & Beeld & $50 \%$ & Rapport \\
& $36 \%$ & Rapport & & \\
Radio and television & & & & \\
programmes & $76 \%$ & News and current affairs & $69 \%$ & Documentaries \\
& $76 \%$ & Documentaries & $66 \%$ & News \\
& $58 \%$ & Movies & $56 \%$ & Sports \\
\hline
\end{tabular}


graduated, drives a sedan and works as a manager for a company in Pretoria where he earns approximately R150 000-00 per annum. The family loves to visit the Kruger National Park at least once a year and stays for five days.

They heard about the park from their friends and family and regularly see articles in Getaway as well as in documentaries on television. Chris and Penny enjoy watching game as well travelling. They visit the Kruger National Park to relax and enjoy themselves. They enjoy the Kruger National Park because of the variety of game. Because Chris and Penny prefer and love this park, they do not visit privately owned game reserves and remain brand loyal.

\section{Conclusions and recommendations}

The aim of this paper was to determine the profile of a typical tourist visiting the Kruger National Park. From this research the following conclusions can be drawn:

- there is not a notable difference between the results, therefore a change from the months May to July, of the surveys done in 2001 and 2002. What does change, however, is that there are more foreign tourists in this park in July than in May. This might be explained by the fact that it is then the European summer holidays;

- a specific market segment has been determined, portrayed by Chris and Penny, which can streamline all marketing efforts and makes it easy to target this particular market;

- tourists visiting the KNP are brand loyal and a quality service should sustain this market well into the future. This creates a situation where marketers can identify other potential markets to focus on them;

- needs of current tourists are basically the same, which makes it easy for the park to gain a larger part of the market.

Based on the conclusions the following recommendations can be made:

- From a marketing point of view, park management knows who the target market is, especially during the months of May to July. The marketing message for the international market should therefore focus on the fact that May to July is the best game viewing months of the year. If the policy is to focus primarily on the domestic market during these months, then the status $q u o$ should be maintained. From a management policy point of view, an analysis of certain aspects of the profile, e.g., spending, can give important information on how to create a situation where tourists can spend more money. One way of addressing the latter is by the development of more recreational facilities for children. This will not only lead to more spending in the park but also to investing in a future market for this and other parks. Other parks can take note of these results and implement similar research in order to compare results.

\section{Acknowledgements}

The authers would like to acknowledge Dr Suria Ellis of Statistical Services for the statistical analysis.

\section{References}

AAKER, D.A. 1998. Strategic market management. New York: Wiley.

Andereck, K.L. \& L.L. CALdwell. 1994. Variable selection in tourism market segmentation models. Journal of Travel Research 33: 40-46.

DenNIS, N. 2000. Kruger: Images of an African Park. Cape Town: Struik.

Doole, I. \& R. Lowe. 2001. International marketing strategy. London: Thomson Learning.

HASSAN, S.S. 2000. Determinants of market competitiveness in an environmentally sustainable tourism industry. Journal of Travel Research 38: 239-245.

Kinnear, T.C., K.L. Bernard \& K.A. Krenter. 1995. Principles of marketing. New York, NY: Harpercollins.

Kotler, P., J. Bowen \& J. Makens. 1999. Marketing for hospitality and tourism. Upper Saddle River, NY: Prentice Hall.

Lamb, C.W., J.F. Hair \& C. McDaniel. 2002. Marketing. Australia: Thomson Learning.

LAWs, E. 1997. Managing package tourism. London: International Thomson Business Press. 
McDonald, M. \& I. Dunbar. 1995. Market segmentation: a step-by-step approach to creating profitable market segments. London: MacMillan.

Nickels, W. G. \& M.B. Wood. 1997. Marketing: relationships, quality, value. New York: Worth.

PENDER, L. 1999. Marketing management for travel and tourism. Cheltenham: Stanley Thomas.

PloG, S. 1976. Increasing your sales to new and existing markets. Florida: Plog Research, Inc.

Pride, W.M. \& O.C. Ferrell. 1987. Marketing. Boston: Houghton Muffin Company.

PRITCHARD, M.P. 1998. Responses to destination advertising: differentiating inquirers to a short, getaway vacation campaign. Journal of Travel \& Tourism Marketing 7: 31-68.

PROCTOR, T. 1996. Marketing management: integrating theory and practice. London: International Thomson Business Press.
REISINGER, Y. \& L. TURner. 1998. Cross differences in tourism: a strategy for tourism marketers. Journal of Travel \& Tourism Marketing 7: 79106.

SaAYman, M. 2001. Tourism marketing in South Africa. Potchefstroom: Institute for Tourism and Leisure Studies.

SAT (South African Tourism). 2002. South African Tourism: Business plan \& budget version. Johannesburg: South African Tourism.

SEMENIK, R.J. 2000. Promotion and integrated marketing communications. Canada: Thomson Learning.

SLABBERT, E. 2002. Key success factors of tourist market segmentation. MA dissertation. PotchefstroomUniversity for Christian Higher Education.

Strydom, J.W., M.C. Cant \& C.J. Jooste. 2000. Marketing management. Cape Town: Juta. 